\title{
Varjusurma fenomenist läbi ajaloo, kirjanduse ja folkloori
}

\author{
EDA KALMRE
}

Metafoorses tähenduses on varjusurm (ingl seeming death, sks Scheintod) tänapäevalgi eesti keeles aktiivses kasutuses. Sellega märgitakse tavaliselt midagi, mis on küll olemas, aga ei toimi, siinkohal olgu näiteks mõned juhupealkirjad meediast: „Aktsiafondid on varjusurmas”, „Hüpnoosravi Eestis on varjusurmas” jne. Samal ajal ei ole selle sõna sisuline tähendus päriselt ununenud ega avalikkusest kadunud. Aeg-ajalt leiab ajakirjandusest rahvusvaheliste teabeagentuuride tõlkelugusid uudistest, kus keegi surnuks arvatu on ootamatult enne matuseid ellu ärganud. Need sensatsioonilised uudised on interneti kaudu altid levima ühest väljaandest teise, riigist riiki, ilma et väljaanded nende tõeväärtust kontrolliksid.

Surma tuvastamise teema ja varjusurma fenomen oli Euroopas kõneaineks juba sajandeid tagasi. Surnute elluärkamise tõsielulised või arvatavalt reaalsed juhtumid on leidnud kajastamist nii suulises pärimuses, kirjanduses, varases ajakirjanduses kui ka meditsiinikirjanduses. Esimesed viited varjusurmale ulatuvad antiikaega ja kirjeldavad mõnda konkreetset juhtumit. Tuntuim (ja viidatuim) neist lugudest pärineb Platonilt, kes kõneleb oma „Vabariigis” lahingus tapetud armeenia sõdurist. Kui tema surnukeha kümme päeva hiljem üles korjati, leiti see veel terve olevat, see viidi koju ja kui seda põletama hakati, see elustus (Bonderson 2001: 19). Walesi ülikooli meditsiinikolledži professor Jan Bondersoni monograafiat „Buried Alive. The Terrifying History of Our Most Primal Fear” („Elusalt maetud. Meie ürgse hirmu hirmutav ajalugu”) kunagi inimkonda vallanud elusalt matmise hirmu kohta võib lugeda üheks ammendavamaks tänapäevaseks käsitluseks, mis võtab varjusurma fenomeni avamisel arvesse paljude erinevate valdkondade allikaid ja aspekte. Bondersoni raamatuga samal aastal ilmus ka teine antud teema üsna põhjalik ajalooline ja folkloristlik käsitlus Ines Köhler-Zülchilt (2001, vt ka selle eestikeelset tõlget Köhler-Zülch 2012). Need autorid on teinud oma uurimusi kumbki omaette ja sellest tulenevalt teineteise tööle ei viita, ometi kasutavad nad sarnaseid allikaid ning jõuavad mitmele sarnasele järeldusele. Toetudes mainitud käsitlustele, pakun käesolevas artiklis sissevaate varjusurma teemasse läbi rahvaluule, kirjanduse, meditsiini, religiooni ja ajakirjanduslike allikate ning keskendun XVIII-XIX sajandi ja XX sajandi esimeste kümnendite sellealasele materjalile Eestis. 


\section{Varjusurm meditsiinilisest aspektist}

Varjusurm on pigem rahvalik termin sügava une taolise seisundi kohta, mida varasematel sajanditel ei õnnestunud ka arstidel tihti kindlaks teha. Sel juhul on inimese ainevahetus vähenenud miinimumini, hingamine ja südametegevus pole välispidiselt tajutavad. Seisund võib kesta päevi või isegi nädalaid. Niisugused sümptomid on iseloomulikud mitmele haigusele ka tänapäeval, neid võib esineda vastsündinuil, suure verekaotuse, mürgituste (oopium, kloroform) puhul. Meedikud on välja pakkunud, et näiteks vanad rahvajutud uinuvast kaunitarist võivad viidata just sellele nähtusele (vt Kliinik.ee: varjusurm). Teatud haiguste puhul, nagu diabeet jms, on võimalik, et inimene langeb koomasse ja n-ö tuleb tagasi. Tänapäeva meditsiin kutsub niisugust elluärkamist piiblile tuginedes ka Laatsaruse sündroomiks.

Tähtis otsus surma tuvastamise vallas tehti 1968. aastal, kui lepiti kokku nn Harvardi kriteeriumis, mis konstateeris ajusurma, st kõigi aju funktsioonide lakkamise. Sellises pöördumatus seisundis patsiendid kuulutatakse surnuks ja nende organeid võib võtta siirdamiseks (vt Lehtmets, Elmet 2013). Jan Bonderson (2001: 270-272) märgib, et isegi pärast Harvardi kriteeriumi seadmist püsisid kahtlused ja hirm elusalt lõikuslaua peale sattuda veel peaaegu kümnendi, sest vaidlused meedikute endi vahel kestsid edasi, tehti spetsiaalseid katseid lisauuringuteks, kasutades elektroentsefalograafiat peaaju bioelektrilise aktiivsuse mõõtmiseks. Oma osa kahtluste õhutamisel oli ka lääne ajakirjandusel. Alles 1980. ja 1990. aastatel muutus ajusurm üldiselt aktsepteeritavaks.

\section{Murrang valgustusajastul. Meditsiin ja tavad läbi mitme sajandi}

Mitmete asjaolude koosmõjul sai valgustusajastul üks inimese ürgsemaid hirme, tafefoobia - hirm elavalt maetud saada -, korraga väga aktuaalseks. Veel XVII sajandi meditsiinis eksisteerisid kõrvuti teaduspõhiste arusaamadega ka paganlikud müüdid, religioossed legendid ja populaarsed uskumused. Surma defineeriti kui seisundit, kus elu kustus ja hing ühtaegu lahkus kehast; inimene sai olla kas elus või surnud, puudus niisugune asi nagu suremise protsess. Surma suhtuti kui üleloomulikku, segasesse fenomeni, mis asus väljaspool ratsionaalse analüüsi võimalust. (Bonderson 2001: 22-23) XVII sajandi Inglismaa katkuepideemiate ajal on sugulasi ja arste süüdistatud selles, et nad tahtlikult matsid nakatunuid elusalt (Slack 1985: 274-275). Aga samal sajandil hakkas suhtumine surma ja suremisse muutuma. Varjusurmahirmust XVIII sajandil annavad tunnistust näiteks katkuohvrite matusepaigad. Marseille's on väljakaevamistel ühest niisugusest leitud surnuid, kelle sõrmedesse olid torgatud pikad nõelad, et veenduda, kas inimene on ikka päriselt surnud. Seda surma kindlakstegemise meetodit kasutati ka hiljem laialdaselt. (Bonderson 2001: 32-33) XVIII sajandil sai surma ja elu tundemärkide ning suremisprotsessiga kaasnevate ilmingute ebaselgusest meditsiiniteaduslik probleem, millele (nagu eespool märgitud) veel XX sajandilgi lahendust otsiti. Piir elu 
ja surma vahel hägustus, hakati määratlema üleminekuseisundit, varjusurma, mille reaalne tuvastamine käis isegi koolimeditsiinil, aga veel enam tavalisel hariduseta talupojal üle jõu. Nimelt peeti veel XIX sajandil laibalehka kõige pädevamaks meditsiiniliseks tõenduseks inimese lõpliku lahkumise kohta. Tollane arenev meditsiin ja tervishoiupoliitika tegid kõik, et süvendada hirmu ja hoiatada inimesi elusalt matmise eest. Abimeetmetena püüti rakendada erilist koolnuvaatlust ja seadusandlikult matmistähtaegu pikendada. (Köhler-Zülch 2012: 179)

XVIII-XIX sajandi meditsiin oli otsiv ja arenev, tehti ridamisi olulisi avastusi (nt siberi katku tekitaja (1876) ja tuberkuloosikepikese avastamine (1882); XIX sajandi esimestel aastatel toimusid Tallinnas esimesed vaktsineerimised rõugete vastu; 1830. aastal hakati vahet tegema süüfilisel ja gonorröal (vt Gustavson 1969: 47, 1979: 12). XIX sajandil hoogustus Euroopas liikumine enneaegse matmise vastu. Muu hulgas loodi ka vastavaid ühinguid, üheks kõige mõjusamaks oli 1896. aastal asutatud London Association for the Prevention of Premature Burial (Londoni ühing enneaegse matmise vältimiseks). Ühing avaldas ajakirjanduses lugusid õnnetul kombel maha maetud veel elusatest inimestest, varjusurmas sünnitajatest ja muust sellisest ning püüdis Briti parlamendis läbi suruda seadust, et inimest ei maetaks ilma meediku antud tõendita ega antaks tõendit ilma surnut põhjalikult uurimata. ${ }^{1}$ Algselt ühtis varjusurma teema esile kerkimine valgustusajastul selle aja valitseva klassi, haritlaste, arstide ja majandus- ning usuringkondade üldiste püüdlustega inimesi harida, n-ö maailma parandada.

Meditsiiniliste asjaolude parema näitlikustamise, probleemi tõsiduse toonitamise ja materjali atraktiivsema esitamise huvides kasutati juhtumikirjeldusi varjusurmast ellu tagasi pöördunud inimestest või varjusurma järel ekslikult maha maetud ja selle tagajärjel päriselt hukkunud inimestest. Ühed kuulsamad ja mõjusamad meditsiinialased teosed, mis kujundasid üldist suhtumist, külvasid hirmu ja segadust ning levitasid folkloori XVIII ja XIX sajandi Euroopas, olid Jacques Jean Bruhieri „Dissertation sur l'incertitude des signes de la mort et l'abus des enterrements et embaumements précipités” (I-II, 1742-1745, „Käsitlus surmamärkide usaldusväärsusest ja enneaegse matmise ja balsameerimise tagajärgedest" $)^{2}$ ja tuntud arsti Christoph Wilhelm Hufelandi (1762-1836) ${ }^{3}$ nn varjusurma sõnaraamat „Der Scheintod oder Sammlung der wichtigsten Thatsachen und Bemerkungen darüber, in alphabetischer Ordnung” (1808, „Varjusurm ehk seda puudutavate olulisemate faktide ja

\footnotetext{
${ }^{1}$ Poliitika ja meedia mõjutamise kõrval publitseerisid ühingu asutajad William Tebb ja Edward Perry Vollum üsna populaarseks saanud raamatu „Premature Burial: How It May Be Prevented” („Enneaegne matmine: kuidas seda ära hoida”, 1896, vt Hartzman 2017).

${ }^{2}$ Teos sai üsna varsti kättesaadavaks ka saksakeelses tõlkes „Abhandlung von der Ungewißheit der Kennzeichen des Todes und dem Mißbrauche der mit übereilten Beerdigungen und Einbalsamirungen vorgeht" (1754).

${ }^{3}$ Hufeland kirjutas varjusurmateemalise doktoriväitekirja juba 1783. aastal. Ta oli tüüpiline valgustusajastu teadlane, kes peale surmasümptomitega tegelemise pani suurt rõhku tavaliste inimeste harimisele. Eestikeelsena on ilmunud tema õpetused „Kunst, kuidas kaua elada võib” (Hufeland 1904). Raamatuke sisaldab mitmeid tänapäevalgi kaasaegselt mõjuvaid õpetusi stressivaba elu, toitumise, hügieeni, vananemise ja haiguste kohta.
} 
arvamuste kogu tähestikulises järjekorras"; vt Bonderson 2001: 13, 57-71, 191-192 jm; Köhler-Zülch 2001).

Köhler-Zülch ja Bonderson näitavad oma uurimustes, kuidas arvatavates juhtumikirjeldustes segunesid faktid ning fiktsioon, folkloor ja kirjanduslikud töötlused. Mõlemad autorid märgivad, et varjusurma teema püsis Euroopas valgustusajastul aktuaalsena neljale tegurile toetudes: arenev meditsiin; ajakirjandus; kirjandus ja rahvaluule; kirik ja religioon. Kõik need valdkonnad püüdsid rahvast teavitada ning kasvatada ja jutustasid üha ümber vanu ning uusi lugusid juhtumitest, kus oli või võis olla tegemist varjusurmaga. Kogu selle teema kulgemise haripunktis võeti ka riiklikult kasutusele surma ja matmisega seotud reegleid ja seadusi. Tõsiasi oli, et paljud selleaegsed trükiväljaanded õhutasid varjusurma hirmu ja see omandas XIX sajandi keskpaigaks lausa hüsteeria mõõtmed (vt Köhler-Zülch 2012: 180). Ehitati spetsiaalseid haiglaid surnute jälgimiseks, märguandekelladega kirste jms. Enneaegse matmise vastane liikumine oli kõige intensiivsem Saksamaal, kus tegutses ka Hufeland, kelle kodulinnas Weimaris ehitati esimene surnute jälgimise haigla (sks Leichenhaus) juba 1792. aastal. Aga enneaegse matmise vastasel liikumisel oli jõudu ka Prantsusmaal, Inglismaal ja mujal. XIX sajandi keskpaigaks olid küll mitmed varjusurnute haiglad Saksamaal kas lammutatud või uue kasutuse leidnud, ometi tegutsesid nad suuremates linnades, nagu Frankfurt, Mainz, München ja Berliin, ikka edasi. Uued sarnased asutused avati 1870. aastatel veel Düsseldorfis, Stuttgardis ja Hamburgis. (Bonderson 2001: 90-91, 104, vt ka 88-117)

On teada mitmeid tuntud inimesi, kes olid elavalt matmise hirmu kütkes, näiteks kirjanikud Hans Christian Andersen, Fjodor Dostojevski, keemik Alfred Nobel. Ka Nikolai Gogol (1809-1862) kartis eluajal letargilises olekus matmist ja hilisemate kuulujuttude kohaselt just nii juhtuski. Kui 1931. aastal kirjaniku haud ümbermatmiseks avati, olevat keha olnud veidi teises asendis ja väidetavalt olla ka kirstukaant kraabitud. Kuigi sel hetkel pakuti juhtunule teisigi seletusi, püsib spekulatsioon elusalt matmisest siiani paljudes Gogoli elu ja surma käsitlevates kirjutistes (Wikipedia: Nikolai Gogol). Mitmed XIX sajandi tuntud kirjanikud puudutasid elavalt matmise teemat oma teostes: nt Gottfried Keller (1819-1890) poeemis „Liebedich begraben”, Edgar Allan Poe (1809-1849) jutustuses „The Premature Burial” jmt.

\section{Varjusurma temaatika Eestis}

Vaadeldes erinevaid allikaid, tundub, et Ida-Euroopa maadesse, sh Eestisse jõudis varjusurma langemise hirm ja probleem mõnevõrra hiljem ning sai ehk tunduvalt vähem kõlapinda, aga ometi oli see ka siin olemas ning kajastus tavaelus, ajakirjanduses, seadustes, igasugu meetmetes ja muidugi folklooris: muistendites ja kuulujuttudes.

Mitte ainult Eestis, vaid ka naabermaades kirjutati XIX sajandil igasugustest juhtumitest, kus kahtlustati varjusurmas olekut. Näiteks 1880. aastatel ilmus vene meditsiiniajakirjas mitmeid artikleid varjusurmast. Ühes neist oli kirjeldatud juhtumit, kus haud kaevati lahti, sest matuste ajal olla nähtud surnu silmist pisaraid 
voolamas. Küla või kihelkonna vaimulik oli sel ajal tihtilugu arsti õigustes ja tema oli see, kes pidi surma tuvastama. On teada, et XIX sajandil andis Kiievi usuakadeemia välja spetsiaalse käsiraamatu preestritele selle kohta, kuidas surma tuvastada (Warner 2000: 73-74). Talurahvastki püüti teavitada. Esimesed trükised eesti talurahva kodudes olid kalendrid ja juba XVIII sajandi kalendritest võib leida õpetusi, kuidas inimesi elustada külmumise ja uppumise ning varjusurma korral. Niisuguseid õpetusi võib leida näiteks 1793. aasta „Eesti-Ma Rahva Kalendris” ja Friedrich Gustav Arveliuse „Ramma Josepi Hädda- ja Abbi-ramatus” 1790. aastal (vt Martsoo 2007: 11).

Eestis arvas kirik, et matustega kiirustamist ja surnuvalvamist võib eestlaste juures pidada paganlikuks nähtuseks. Selles kontekstis on mõistetav, miks just kiriklikud ringkonnad õhutasid hirmu elusalt matmise ees, tõrjudes traditsioonilist perekondlikku surma- ja matusekombestikku.

Kirikul oli põhjust olla rahulolematu. Mitmest eestlaste ja nende sugulasrahvaste matusekombeid analüüsivast kirjutisest võime lugeda (vt Reiman 1915; Mikkor 1994, 1995), et eestlased ei olnud väga altid kristlikke kombeid täitma, ehkki nad olid uue usu vastu võtnud juba mitu sajandit tagasi. Kirde-Eesti surmakultuuri uurinud Merike Lang on mõnele XVI ja XIX sajandi allikale tuginedes (David Dubberich, Johann Wilhelm Ludwig von Luce) märkinud, kuidas tegelikkuses püüti surnuid matta nii kiiresti kui võimalik (Lang 2004: 84). Seda ilmselt mitmel põhjusel: üks neist oli vaesus, sest surnuvalvajatele tuli pakkuda süüa ja juua, teine oli surnule pühendatud aeg, mis ei lubanud tööd teha. Kirik püüdis surnuvalvamise kombele anda uut sisu (Rimpiläinen 1971: 207, 259). 1799. aastal võeti vastu kirikuseadus, millega keelati pesta haigeid või „nähtavasti” surnuid, enne kui need polnud täielikult kangestunud ning igasuguseid elumärke kaotanud, ja matustega tuli oodata kolm päeva (Rosenplänter 1823).

Võib arvata, et XIX sajandil kuulus hirm elavalt maetud saada inimeste igapäevaelu juurde. Sellest kirjutati, sellest räägiti, levisid kuuldused ja pikemad traditsiooniliste süžeedega lood (rändmuistendid) varjusurmas viibimise ja elusalt matmiste kohta. Lisaks visati selle üle nalja ning needsamad romantilised lood andsid üksiti ainet rahvalikele ballaadidele.

Ühed kõige ekstreemsemad meetmed, mis elavalt matmise vastu ette võeti, olid juba eespool nimetatud spetsiaalsed asutused surnute jälgimiseks, nn varjusurnute haiglad, ja spetsiaalsed märguandevõimalusega kirstud. Niisugust materjali pole eraldi talletatud, aga ühe suulise teate järgi olevat vähemalt ühel korral Tartus Raadi surnuaias niisugust märguandega kirstu kasutatud. ${ }^{4}$ Varjusurnute haigla rajati Tallinnasse peavaksali lähedusse siin elanud veidrikust arsti Heinrich Heinrichseni (1781-1855) sihtotstarbelise päranduse eest 1860. aastatel. ${ }^{5}$ Hüpnoosist ja homöopaatiast huvitatud Heinrichsen oli terve eluaja vaevelnud elavalt matmise hirmu-

\footnotetext{
${ }^{4}$ Teade pärineb vaimulik Urmas Oraselt, kellele rääkis seda üks XX sajandi alguses sündinud naine Tartu hooldekodus aastaid tagasi.

${ }^{5}$ Haigla avamisaega on mõnevõrra erinevalt dateeritud: Valdeko Vende pakub 1865. aastat ja Heino Gustavson aastat 1869. Teist, küll mitte varjusurnutele, vaid vaeste linnakodanike ravimiseks mõeldud haiglat püüti Heinrichseni sihtkapitali abiga rajada XX sajandi algupoolel, vt Vende 1990: 50 ja Gustavson 1979: 148, 204.
} 
mõtte käes (Gustavson 1979: 204; Vende 1990: 50-51). Sellest kummalisest haiglast on humoorikas võtmes kirjutanud Werner Bergengruen (1892-1964) oma lühijutustuses „Kummaline varjupaik” (Bergengruen 1966).

\section{Varjusurma teema eesti rahvaluules}

Osa varjusurmaga seotud motiive ning jutusüžeesid on vanad ja tuntud üle ilma, kuid soodne pinnas süžeede kujunemiseks ja aktiivseks levikuks mitme sajandi vältel tekkis Euroopas alles valgustusajastul. Eesti Rahvaluule Arhiivi kogutud varaseimad tekstid pärinevad 1880. aastate lõpust ning hiliseimad on üles kirjutatud 2000. aastal. Käesoleva artikli autorgi on neid oma 1986. aastast alanud igasuvistelt välitöödelt üksjagu jäädvustanud ja need on andnud ainet ka üheks ülevaatlikuks ettekandeks (Kalmre 1988).

Enamik eesti varjusurmajutte on kogutud just XX sajandi teisel poolel. Selle üks võimalikke põhjusi on, et suur osa temaatilisest ainesest ringles rahvaluulekogumise algusaegadel, XIX sajandi lõpukümnenditel ja XX sajandi alguses, kuulujuttudena, st justkui oleks kellegi kaasaegsega, tuttava tuttavaga niisugune lugu tegelikult aset leidnud. Selleaegsete kriteeriumide järgi ei osanud rahvaluulekogujad näha nende juttude traditsioonilist sisu, pidades seda igapäevaelu kajastavaks informatsiooniks, seda enam, et näiteks XIX sajandi ajakirjanduses avaldati sarnaseid uudiseid väidetavalt tõestest varjusurma juhtumitest.

Järgnevad katked 1970.-1980. aastatel Eesti Rahvaluule Arhiivi jaoks salvestatud juttudest annavad märku elavalt matmise teema ja isegi kunagise hirmu kohalolust veel XX sajandi viimastel kümnenditel.

(1) Minu ema sugulane jäñnd sünnitamisega varjusurma.

(2) See juhtus siinsamas Lelles.

(3) Kui mu vanaema nägi mõnd surnud inimest unes, siis arvas, et see on varjusurmas.

(4) Kui minu onu ära suri, isa arvas, et äkki on varjusurmas, läks ja vaatas peegliga kas hingab, on olnud ju inimesi varjusurmas.

(5) Üks ämmaemand tahtnud, et temal käesooned läbi lõigataks, et muidu tema jääb varjusurma.

(6) Lapsena ajasid need varjusurma lood päris hirmu peale, neid räägiti tihti.

(7) Minu nooruses käis jutt, et mitte hoida enne matuseid kodus, vaid viia kuhugi kliiniku ja surnut mitte kohe matta, hoida mitu päeva.

Jättes kõrvale varjusurma sugemetega muinasjutud („Uinuv kaunitar”, „Okasroosike”, „Lumivalguke”), võib eesti traditsioonis rahvajuttude tüübikataloogide järgi (Uther 2004; Simonsuuri 1987) tuvastada varjusurma juttude nelja süžeelist arendust.

Esimene, „Naine teeskleb surnut”, eesti materjalis pigem „Varjusu rmas mõ rsja" (885A), on määratletav nn novellilaadse muinasjutuna. Selle sisu on lühidalt järgmine: noor naine (printsess) armub vaesesse mehesse. Aga 
tema vanemad sunnivad teda teisega naituma. Oma pulmapäeval langeb naine varjusurma (minestab, ajab midagi kurku). Peig kuuleb hauast hääli, kaevab haua lahti, päästab tüdruku ja nad abielluvad. Tüdruku päästjaks võib olla ka hauaröövel. Mõnel juhul maetakse maha tüdruku vahakuju. Süžeed on nimetatud ka romantilise motiiviga muistendiks ja seda on üles kirjutatud kõige enam Kagu-Eestist, täpsemalt Setumaalt. Jutt on Hiina algupäraga, selle Euroopa versioonid pärinevad keskajast („Dekameroni” 10. päeva 4. novell, vt Boccaccio 2004: 609-614; Uther 2004: 510).

Nn olustikulise muinasjutuna või muistendina on määratletav teine tüüp „Varjusurnu/näiliselt surnu elustub” (990, Uther 2004: 617 või C1901 soome muistendiainese põhjal, vt Simonsuuri 1987: 67). Naine jääb haigeks epideemia ajal ja langeb surmasarnasesse seisundisse. Ta pannakse hauda koos kalli sõrmusega. Kui hauakaevaja tuleb hauda röövima, ärkab naine sõrmuse sõrmest kättesaamisel ellu, läheb koju ja elab veel kaua. Mõnel juhul naitub ta hauaröövliga (liitumine süžeega 885A). Jutt on dokumenteeritud hilisel keskajal (vrd „Dekameroni” 2. päeva 5. novelli ja 10. päeva 4. novelli, Boccaccio 2004: 93-101, 609-614). Jutt on tuntud kogu maailmas (Uther 2004: 618). ${ }^{6}$ Need kaks siin nimetatud süžeed lõpevad tavapäraselt õnnelikult ja arvatavalt surnu ärkab ellu.

Kolmas süžee „Rase naine langeb varjusurma” (C1921, vt Simonsuuri 1987: 67) pole tavapäraselt enam õnneliku lõpuga: naine maetakse, ta sünnitab hauas ning sureb. Nendes juttudes annab varjusurmas matmisest tunnistust hauas sündinud laps (või lapsed). Hauast kostvad häl̈led ja lahtikaevamisel kirstust leitud laste luustikud on neis lugudes selle koletu sündmuse tunnistajateks.

See oli siinsamas Lelles, Nassa majas oli. Noor naine olnd ja surnd ära. Olnd rase ka. Näidand ennast kangesti unes mehele ja vanematele. Midagi ikka rääkis neile unes ja nad olid ta välja kaevanud. Ta oli seal puusärgis veel lapse sünnitand. See imeasi küll, kuidas ta seal ummukses nii kaua elas. (EKM ERA, RKM II 402, $164(19)<$ Juuru, Ingliste v, Palu k - A. Korb < Aliide Kallis, 79-aastane (1987))

Mõnel juhul võivad varjusurmas mõrsja ja varjusurmas sünnitaja rollid omavahel liituda. Enamasti on siin nimetatud jutuarendustes peategelaseks noor naine. Samavõrra nagu neil traditsioonilistel lugudel oli soodus pinnas levimiseks XVIII ja XIX sajandi meditsiinilise kirjanduse juhtumikirjeldustena, olid nad populaarsed ka ilukirjanduses. Õigupoolest olidki piirid nende žanride vahel hägusad. Sellest annavad tunnistust võõrapärased tegelaste nimed, romantilisuse poole kalduv sisu jms. Siin teisena nimetatud süžee on maailmas tuntud ka kui „Sõrmusega leedi”. See kohalikku olustikku tõlgitud ja kohalikud tegelased saanud lugu on olnud XIV-XIX sajandil Euroopas väga paljudes linnades üks populaarsemaid rändmuistendeid. Näiteks Iirimaal on Shankilli surnuaeda püstitatud hauakivi leedi Margorie McCallile, kes väidetavalt elusalt maha maeti ja tänu hauaröövlitele kirstust pääses, Saksamaal on XVII-XIX sajandist teada vähemalt 19 linna, kus on juhtunud analoogne lugu (Wikipedia: Lady with the Ring; vt ka Bonderson 2001: 35-71). 1988. aasta

\footnotetext{
${ }^{6}$ Näiteks vene muinasjuttude kataloogis on jutt sama tüübinumbriga ja kannab nime „Röövel päästab elusalt maetu” („Заживо погребенную спасает грабитель”, vt Barag 1979: 252-253).
} 
Puhja välitöödel kirjutasin üles sentimentaalsevõitu versiooni väidetavalt Miitavis (Jelgavas) juhtunud loost, jutustajaks oli 83-aastane Hilda Pääsuke.

Olli kunagi üts mõisaprovva olnu, Miitavi linnast viil peri. Surnu ära ja kõik matusse peeti ära. Aga tuu surnuaiavaht, tuu väega kehvast elanu, tal olnu mõni katsteistkümme last. Aga mõisaprovval olnuva uhke matusse ja pallu kulda pantu üten, sõrmussid ja kõiki. Mõtelnu sis, et vaja võtta omale. Aga tollel olnu 12-aastane tütrik ja lännu isale järgi surnuaida. Tüki aja pärast isa tulnud joosuga surnuaia mant ja lännu tiigi manu. [---] Tütrik küsinu isa käest, et kos sa lähat. Isa tüknu ike tiiki. Tütrik hoidnud isal käest kinni ja nigu rahustanu teda.

Kae tema sääl kabelin kaevanu havva lahti ja tahtnu toda sõrmust säält provva sõrmest kätte saada. Võtt' noa ja noa otsaga urgits, aga verist näpu ära ja provva ärgas ülesse. Tolle perast tuu kabelivaht tüksegi suure ehmatusega sinna tiiki. Provva tõusnu ülesse ja tulnu sis tagasi, et minge ruttu, kabelivaht tahab ennast ära uputada. Tõise ehmatanuva ära, et vaim, aga perast ike vaadanuva, et inimene ja lännuva sinna tiigi manu. Tuu 12-aastane tütrik hoidnud sis isa kinni niikavva. Aga kavva ta oles jõudnu hoida! Päästnuva tolle kabelivahi sis ära. Tema pärast selet härrale, et ta nii vaeselt elap. Härra olnu rõõmus, et naine tagasi, andnu kabelivahile hobuse, lehma ja seapõrsa, üte tüki maad kah viil. Aga see om tõestisündinu lugu. Tuu provva kelle man mul emä teense oll kah Miitavist peri, tuu kõneles. (EKM ERA, RKM II 413, 483/5 (22) < Puhja, Kuiduaru k - E. Kalmre < Hilda Pääsuke, 83 a (1988))

Need lood võivad olla esitatud üsna romantilises võtmes, näiteks abiellub rikas parunipreili oma vaese röövlist päästjaga. Varasele sentimentaalsele rahvalikule kirjasõnale, mis ammutas ideid ka ühiskonnas üldiselt aktuaalsetest teemadest ning rahvapärimusest, oli varjusurma kui nähtuse esiletoomine üsna iseloomulik. Meie päevini rahvajuttude ja kirjanduse kaudu kandunud lood on tihtilugu seotud mõne kuulsast soost noore naisega. Eesti traditsioonis on küllap üks kuulsamaid varjusurmas sünnitajaid olnud Kullamaa kirikusse maetud Preisimaa hertsogi tütar ja Braunschweigi vürstitar Auguste Friederike Luise, kes saadeti Peterburist õukonnaintriigide pärast Eestisse Koluvere lossi pagendusse. Eestis ei käinud noore vürstitari käsi aga kuigi hästi. Kohalikus traditsioonis on siiani tuntud lugu õnnetust Friederikest, kes kirstus sünnitas ja maeti koos oma vastsündinud lapsega (vt Kaljund 2012). ${ }^{7}$

Eesti traditsioonis on vähem esindatud usundiline muistend varjusurnust, kes tõuseb ellu enne matuseid (C1931), aga ei tohi rääkida sellest, mida surnud olekus nägi. Tekstis öeldakse, et niisugune inimene sureb tavaliselt aasta, kolme või nelja pärast.

Vanasti olnud Tammikus Rebuoja metsa ääres maja. Sääl surnud peremees ära. Naine ja viis last jäänud järele. Naine nutnud väga ja kutsunud puusärgi tegijad. Kui

\footnotetext{
${ }^{7}$ See maailma poliitiliste suurkujudega seotud lugu on mitmetel kordadel pälvinud kohaliku meedia tähelepanu, viimati 9. oktoobril 2019 ETV saates „Pealtnägija”, kus see sai sootuks tänapäevase konteksti, sest Friederike öeldi olevat parasjagu võimul oleva Suurbritannia peaministri Boris Johnsoni vaarema, vt Pihl 2019.
} 
mehed sinna tulnud, ärkas surnu üless ja käskis tuua kolm suutäit leiba, soola ja vett. Siis öelnud: „Kolme aasta pärast tulge tagasi.” Oma surma olekust keeldus mees rääkimast, mis ta nägi ning kus ta oli. Muidu tema sureb kohe ära. Kolme aasta pärast surnud mees täielikult. (EKM ERA, RKM II 83, 151 (8) < Väike-Maarja - H. Muru < Valdo Mattisen, 86-aastane (1959))

Kui eespool nimetatud jutud sisaldasid ühtseid kindlaid (vahel keerukaidki) süžeelisi tunnusjooni ja esindasid nn folkloorseid jututüüpe, siis märksa tavapärasem on, et alates XVIII sajandist, aga eriti XIX sajandil ja ka XX sajandi algul ringlesid üldise hirmu foonil jutud varjusurmas olemisest, sealt ärkamisest või sellest kahtlusest pajatuse või kuulujutuna. Niisugused jutud olid enamasti ebatavaliste juhtumite lühikirjeldused, mida on seostatud konkreetsete (kohalike) inimeste ja surnuaedadega.

Karijärven kõneliva: sei kanaliha ja väike kont jäi kurku. Nakati matma, lätsiva surnuaida. Ja see oli veel Nosse Miti ema. No obestega mindi, hulk aiga tagasi see oli. Ja põrutanu ja lätski tuu kont valla ja tuliva üten kodu tagasi. (EKM ERA, RKM II 414, 177/8 (18) Puhja, Kaimi k - A. Korb < Alma Sütt, 80-aastane (1988))

Osa neist kuuldustest leidis tee varasesse ajakirjandusse ning nendest tuleb juttu järgmises alaosas.

\section{Varjusurma teema XIX ja XX sajandi alguse Eesti ajakirjanduses}

Eestis levisid nii populaarsed näitejutud kui ka manitsused matmisega oodata ajakirjanduse kaudu XIX sajandil ning veel ka XX sajandi alguskümnenditel. Juba esimese eestikeelse ajalehe Tarto maa rahwa Näddali-Leht teises numbris 1806. aastal ilmus elusalt matmise eest hoiatav artikkel. Kirjutises rõhutatakse vajadust hoida koolnut kolm päeva matmata, sest paljud inimesed olevat juba elusalt maha maetud. Selleski kirjutises peetakse kõige selgemaks surma tunnusmärgiks laibalehka.

Se kige selgemb täht, kustast ärra tunnus, et üts om töttelikkult kolu, om se koolja hais, kumb egga üts tunnep. Kui se hais jo tutta om, sis nakkap se kolu keha käüma ehk üllespaisoma; wat tullep su pääl nink must-sinnitse tähe löwa keha päle. Ni kawwa peap nüüd eggaüts matmissega kannatama, kui se kik tutta om. (Tarto maa rahwa Näddali-Leht: 167)

Et lahendada tööjõu ja talupojale rasket toidupuuduse probleemi, soovitati sellessamas artiklis otsida terve küla peale mõni vanainimene, kes valvamist väikse tasu eest võiks teha, ning soovitati ühtlasi ka surnu külastajatele sööki ja jooki mitte pakkuda. Veel rõhutatakse, et tolle aja seadused nõuavad matustega kolm päeva ootamist. (Issakov, Peegel 1998: 137; Tarto maa rahwa Näddali-Leht: 166-167) 
Vaadeldes XIX ja XX sajandi alguskümnendite Eesti ajakirjandust, võib konstateerida, et n-ö tõsielulised teated kellegi varjusurmas viibimisest olid iseloomulikud XIX sajandile, aga huvipakkuva teemana oli varjusurm aktuaalne veel XX sajandi esimestel kümnenditel. ${ }^{8}$ XIX sajandi teisel poolel võib ajalehtede uudiskülgedelt leida kümneid lühiteateid Eestis aset leidnud juhtumitest. Tihti levisid need „uudised" ühest meediaväljaandest teise, lõppedes sageli sellega, et mõni väljaanne selle tõesena pakutud loo ümber lükkas. Üks iseloomulik näide on Wesenberger Anzeigeris ilmunud ja saksakeelsest St. Petersburg Zeitungist eestikeelsesse ajakirjandusse tõlgitud lugu Kohava vallas elavalt maetud 21-aastasest naisest. Lühiuudis ilmus 1883. aasta jooksul mitmes kohalikus ajalehes rubriigis „Omalt maalt”: Wirulases 9. augustil ja Kündjas 10. augustil. Järgmisest Kündja numbrist võib aga leida uudise ümberlükkamise teate: „Dr. Voss, Viru maakonnaarst, lükkab „St. Petersburger Zeitungis” „Wesenberger Anzeigeri” sõnumi, elavalt maetud naesest, ümber” (Kündja 1883). 1884. aastal avaldas Wirulane uudise kaks korda surnud naisest: „Laiuse surnuaeda, nõnda kirjutatakse meile, maetud 10. märtsil üks elatanud emakene, kes kaks korda surnud" (Wirulane 1884a). Kuu aja pärast lükatakse see teade ümber: „Meie lehes nr 12 seisis üks meile avaldamiseks kätte saadetud sõnum [aga] kadunud emakene ei olevat mitte enne varjusurmas olnud, vaid surnud ja jäänud ka jäädavalt surnuks" (Wirulane 1884b). Kõiki kuuldusi muidugi ei lükatud ümber, näiteks: „Haapsalu ümber kõneldakse, et üks kõrtsimees olla nädali aega surnud olnud ja siis jälle üles tõusnud" (Postimees 1887). Arvata võib, et need ajalehelood levisid ka suuliselt kuulujuttudena, tegelikult töötasid ajakirjandus ja rahvasuu siin vastastikuses koostoimes: ajaleht avaldas kuuldusi ja ajalehes avaldatu levis kuulujuttudena. Peale eelnimetatud näidete leiab uudislugusid varjusurmas oleku kohta veel möödunud sajandi alguse väljaannetest, nagu Päevaleht ja Põhja Kodu.

Ajalehtedes ilmus ka mitmeid pikemaid muistenditel põhinevaid ja kohalikku konteksti „tõlgitud” lugusid. Näiteks 1928. aastal Oma Maas ilmunud pikk lugu on väga sarnane Koluvere lossi vürstitar Auguste Friederike Luise looga ja paigutub muistenditüüpi „Rase naine langeb varjusurma”. See pajatab ühest Saaremaa mõisnikust, kes abiellus vastu ema soovi Tallinna-lähedase mõisavalitseja tütrega. Noor naine jäi lapseootele ja tema abikaasa sõitis asjatoimetuse pärast kodust ära. Vahepeal jõudis noore naise aeg kätte ja kuna ämm tema eest üldsegi ei hoolitsenud, siis langes sünnitaja minestusse. Ämm lasi kohe kirstu tuua ja minia sinna sisse panna. Oma käega naelutas ta kirstu kinni ja lukustas selle toa ukse, kus kirst asus. Teenijaskond kuulis sellest toast karjeid ja oigamist. Ämm aga lasi minia kirstu kähku mulda sängitada. Noor mõisnik tuli koju ja kurvastas väga. Tema kõrvu ulatusid teenijate jutud karjetest lukustatud toas ja ta lasi haua lahti kaevata. Haud avati ja hirmus lugu sai kõigile teatavaks. Noor naine oli surnud, nägu veriseks kraabitud, ning tema jalge juures lebas surnud laps. Südametu ämm kaotas mõistuse ja lõpetas märatseva hullumeelsena. (Oma Maa 1928) Kuigi loo pealkirjas määratletakse seda kui minevikus toimunut (õudne lugu minevikust) ja rahvajuttu (rahvajutt Saaremaalt), on

\footnotetext{
${ }^{8}$ Toetun Eesti ajakirjanduse andmebaaside Dea ja Digar ning Eesti Kirjandusmuuseumi bibliograafia osakonna kartoteegi andmetele.
} 
sellele muistendile tüüpiliselt jäetud alles ka uskumisvõimalus, sidudes süžee kohalike tegelaste ja kohtadega.

Võib öelda, et kuni 1930. aastateni tegeles ajakirjandus varjusurma teemaga üsna aktiivselt. Kuni 1930. aastateni ilmus ajakirjanduses nii erinevaid juhtumikirjeldusi kui ka harivaid ja varjusurma kui meditsiinilise fenomeni üle arutlevaid artikleid. Suurem osakaal oli sel ajal siiski tõlkelugudel, nagu „Varjusurm. Prof. Obolenski järele” (Eesti Postimehe Teaduste eralisa 1904, nr 73, lk 141); „Hirm elusalt maetud saada. Inglise lady, kes oma laibal laskis läbi lõigata kõri” (Esmaspäev. Piltidega nädalaleht, 27. IX 1926); „Kas surnud on tõesti varjusurnud?” (Postimees, 7. VI 1926); „Varjusurma tont. Muumiate ja tinakambri laipade vereproov” (Postimees, 30. IV 1928); „Lõpp varjusurmale. Inimelektri ime” (Postimees, 7. V 1928) jmt.

\section{Kokkuvõte}

Rahvajuttudes on omal moel talletunud inimkonna unistused. Praeguseks on suur osa neis unistustes väljendatud ideedest, nagu lendavad vaibad, seitsme penikoorma saapad jms, ka täide läinud. Lumivalgekese ja Okasroosikese imelise ärkamisega aastaid kestnud pikast unest on aga veel probleeme. See muinasjuttudes väljendatud idee, mida me võime käsitleda ka kui lapselikku unistust ära petta surma, lükates letargilise oleku kaudu edasi lõplikku lõppu, on inimkonna jaoks tänapäeval vahest aktuaalsemgi kui näiteks viiskümmend või sada aastat tagasi. Sellele panustavad tänapäeva teadlased, kes uurivad elu toimimise piire näiteks pikkade mehitatud kosmosereiside tarbeks või inimkeha sügavkülmutamist ajarännaku (ehk siis tuleviku) jaoks. Üht-teist elu ja inimese toimimisaja pikendamiseks on juba saavutatud - näiteks Eestiski pakutakse munarakkude külmutamise teenust selleks, et teha lapsesaamine võimalikuks hilisemas eas. Praegugi on maailmas olemas eraviisilisi krüoonika instituute ja organisatsioone, mis tegelevad surnud inimese või looma keha säilitamisega madalal temperatuuril, eesmärgiga oodata ära elluäratamise ja ravimise võimalus. ${ }^{9}$ Ometi ei ole seni teada juhtumit, kus inimese sellisest olekust äratamine oleks õnnestunud.

Folkloristina pean nentima, et vaevalt on ükski teine teema või rahvajutu arendus andnud žanriliselt nii kireva buketi kui varjusurma oma, ulatudes muinasjuttudest ja romantilise motiiviga muistenditest pajatuste ja kuulujuttudeni. Artiklis ei leidnud kajastamist varjusurmateemalised ballaadid ega naljad, mis samuti Euroopas ringlesid ning mille kohta võib leida üksikuid näiteid ka eesti pärimusest. Jutuuurija perspektiivist on varjusurmajutud põnev näide, kuidas traditsioonilise rahvajutu žanrispetsiifiliselt fiktiivse maailma motiivistik on muistendižanris laienenud reaalsesse maailma, kus kõik toimub tegelikult ja konkreetsete isikutega.

Nähtub, et erinevas meedias (suuline pärimus, ajakirjandus, kirjandus, meditsiini-, kiriku- ning sotsiaalpoliitiline kirjasõna) esile tõusnud ja vastastikku toimiv/ toituv varjusurmateemaline materjal moodustab omamoodi diskursiivse terviku.

\footnotetext{
${ }^{9} \mathrm{Nt}$ USA-s tegutsev Alcor, vt https://alcor.org/ ja Wikipedia: Alcor Life Extension Foundation.
} Vt ka Igavese elu külmkamber. 
Need jutud on küll seotud usundi ja surnutekultusega, neil on müüdiline, muinasjutuline või muistendiline aluspõhi, aga samal ajal käsitlevad need nii inimeksistentsi kui ka kultuuri tahke, mis ei ole usundiga seotud.

Varjusurmajuttude ajaloolist konteksti vaadeldes saab mõistetavaks, kui suurel määral on neid kujundanud meditsiini areng, varane arenev ajakirjandus ning ka omas ajas levinud kirjanduslikud fiktsioonid. Nii nagu paljude surmaga seotud muistendite puhul, mis peidavad endas konflikti kristliku religiooni ja eelkristliku maailmavaate vahel, toob ka varjusurma fenomeni tausta uurimine meile lähemale ja selgitab XVIII-XIX sajandi ajaloolisi olusid, kirikliku õpetuse ja eestlaste paganliku maailmavaate vahekorda. XVIII-XIX sajand kujunes Eestis ajaks, mil kirik lõpuks paganausulise maarahva üle võidu saavutas ning varjusurma teema esilekerkimine aitas sellele kaasa.

Autor on tänulik ajaloolasele Ott Sandrakule kasuliku nõuande eest. Artikkel on seotud Eesti Teadusagentuuri uurimisprojektiga IUT22-5 „Folkloori narratiivsed ja usundilised aspektid", selle valmimist toetas Euroopa Liit Euroopa Regionaalarengu Fondi kaudu (Eesti-uuringute Tippkeskus).

\section{VEEBIALLIKAD}

Dea. Digiteeritud Eesti ajalehed. http://dea.nlib.ee/

Digar. Eesti artiklid. https://dea.digar.ee/cgi-bin/dea

Kliinik.ee. https://www.kliinik.ee

Wikipedia. https://www.wikipedia.org

Lady with the Ring

Nikolai Gogol

Alcor Life Extension Foundation

\section{ARHIIVIALLIKAD}

Eesti Kirjandusmuuseumi (EKM) Eesti Rahvaluule Arhiiv (ERA)

RKM - Riikliku kirjandusmuuseumi rahvaluulekogu

\section{KIRJANDUS}

Barag, Lev Grigor'evič 1979. Sravnitel'nyj ukazatel' sjužetov. Vostočnoslavjanskaja skazka. Leningrad: Nauka. [Лев Григорьевич Бараг (изд.), Сравнительный указатель сюжетов. Восточнославянская сказка. Ленинград: Наука.]

Bergengruen, Werner 1966. Kummaline varjupaik. - W. Bergengruen, Surm Tallinnas. Kurioosseid lugusid ühest vanast linnast. Tlk Rein Sepp. Loomingu Raamatukogu, nr 35, lk 27-40.

Boccaccio, Giovanni 2004. Dekameron. Tlk Johannes Semper. Tallinn: Tänapäev.

Bonderson, Jan 2001. Buried Alive. The Terrifying History of Our Most Primal Fear. New York-London: W. W. Norton \& Company.

Gustavson, Heino 1969. Meditsiinist vanas Tallinnas kuni 1816. a. Tallinn: Valgus. 
Gustavson, Heino 1979. Tallinna meditsiin XIX sajandist kuni 1917. aastani. Tallinn: Valgus. Hartzman, Marc 2017. Proper care for the not-quite-dead-yet: The London Association for the Prevention of Premature Burial. - Weird Historian, 25. IX. http://www.weirdhistorian.com/proper-care-for-the-not-quite-dead-yet-the-london-association-for-the-prevention-of-premature-burial/ (7. I 2020).

Hufeland, Christoph Wilhelm 1904. Kunst, kuidas kaua elada võib / Dr. Hufeland'i järele. Saksa keelest H. Ilves. Laatre: H. Ilves (Viljandi: A. Tõllasepp).

Igavese elu külmkamber. - Maaleht. Lisad: Eakate festival, 3. X 2019.

Issakov, Sergei; Peegel, Juhan 1998. Uusi andmeid esimese eestikeelse ajalehe kohta. Tarto maa rahwa Näddali-Leht. Uurimusi ja allikmaterjale. Koost Tõnu Tannberg. Tartu: Eesti Ajalooarhiiv, Eesti Kirjandusmuuseum, lk 133-156.

Kaljund, Hinge 2012. Printsessi mõrv Koluvere lossis. Tallinn: Kirjastus Canopus.

Kalmre, Eda 1988. Ühest elavast jutust. - Kirjandusmuuseumi VIII kevadsessioon. Ettekannete teesid. Tartu: Eesti NSV Teaduste Akadeemia Fr. R. Kreutzwaldi nim. Kirjandusmuuseum, lk 8-9.

Köhler-Zülch, Ines 2001. Erzählungen über den Scheintod. Faktizität und Fiktionalität in medizinischen Fallberichten. - Folklore als Tatsachenbericht. Toim Jürgen Beyer, Reet Hiiemäe. Tartu: Sektion für Folkloristik des estnischen Literaturmuseums, lk 107-126.

Köhler-Zülch, Ines 2012. Jutustused varjusurmast. Faktid ja fiktsioonid meditsiinilistes juhtumikirjeldustes. - Mis on ühist Gilgamešil ja geeniuurimisel? Käsitlusi kultuurist ja usundist. Koost Reet Hiiemäe. Tartu: EKM Teaduskirjastus, MTÜ Eesti Folkloori Instituut, lk 179-203.

Kündja 1883 = Rakverest. - Kündja, 17. VIII, nr 33.

Lang, Merike 2004. Matusekommetest Kirde-Eestis 19. sajandil ja 20. sajandi algul. - Mäetagused, nr 25, lk 76-102.

Lehtmets, Andres; Elmet, Katrin 2013. Surmast arsti pilgu läbi. [Slaidid.] https://www.etag. ee/wp-content/uploads/2012/05/Andres-Lehtmets.pdf (7. I 2020).

Martsoo, Stella 2007. Ravimitest 18. ja 19. sajandi eestikeelses kalendrikirjanduses. - Mäetagused, nr 36, lk 7-34.

Mikkor, Marika 1994. Surmaga seotud tavadest ersamordva külades Sabajevos ja Povodimovos. - Eesti Rahva Muuseumi aastaraamat XL. Tartu: Eesti Rahva Muuseum, lk 153-184.

Mikkor, Marika 1995. Soikkola isurite matusetavad. - Akadeemia, nr 9, lk 1889-1927.

Oma Maa 1928 = Õudne lugu minevikust. Ämm sulges sünnitaja minija puusärki. Rahvajutt Saaremaalt. - Oma Maa, 4. XII, nr 137.

Pihl, Anna 2019. Boris Johnsoni Eestis surnud vaaremast räägitakse siiani verdtarretavaid lugusid. - Pealtnägija, ETV 9. X. https://menu.err.ee/990141/boris-johnsoni-eestis-surnud-vaaremast-raagitakse-siiani-verdtarretavaid-lugusid (7. I 2020).

Postimees 1887 = Haapsalust. - Postimees, 28. III, nr 14.

Reiman, Helmi 1915. Eestlaste matusekombed. - Eesti Kultura 4. Postimehe kirjakogu. Kokku seadunud Villem Reiman. Jurjev: Postimees, lk 123-163.

Rimpiläinen, Olavi 1971. Läntisen perinteen mukainen hautauskäytäntö Suomessa ennen isoavihaa. (Suomen kirkkohistoriallisen seuran toimituksia 84.) Helsinki: Suomen kirkkohistoriallinen seura. 
Rosenplänter, Johann Heinrich 1823. Ueber Kirchhöfe und Beerdigung der Todten, nebst einem Anhange den Pernauschen Kirchhof betreffend. Pernau: Gedruckt bey Gotthard Marquardt.

Simonsuuri, Lauri 1987. Typen- und Motivverzeichnis der finnischen mythischen Sagen. (FF Communications 182.) Helsinki: Suomalainen tiedeakademia.

Slack, Paul 1985. The impact of the Plague in Tudor and Stuart England. London: Oxford University Press.

Tarto maa rahwa Näddali-Leht. Uurimusi ja allikmaterjale. Koost Tõnu Tannberg. Tartu: Eesti Ajalooarhiiv, Eesti Kirjandusmuuseum, 1998.

Uther, Hans-Jörg 2004. The Types of International Folktales. A Classification and Bibliography. Part I: Animal Tales, Tales of Magic, Religious Tales, and Realistic Tales with an Introduction. (FF Communications 284.) Helsinki: Academia Scientiarum Fennica.

Vende, Valdeko 1990. Ununenud Tallinn. Tallinn: Perioodika.

Vietaniemi, Eliisa 1955. Valekuollut. Helsingin Yliopisto. [Seminaritöö.]

Warner, Elizabeth A. 2000. Russian peasant beliefs and practices concerning death and the supernatural collected in Novosokol'niki region, Pskov province, Russia, 1995. Part I: The restless dead, wizards and spirit beings. - Folklore, kd 111, nr 1, lk 67-90.

Wirulane 1884a = Kaks korda surnud. - Wirulane, 20 III, nr 12.

Wirulane 1884b = Meie lehes... - Wirulane, 17. IV, nr 16.

Eda Kalmre (snd 1958) PhD, Eesti Kirjandusmuuseumi folkloristika osakonna vanemteadur (Vanemuise 42, 51003 Tartu), eda@folklore.ee

\section{The phenomenon of apparent death in history, literature and folklore}

Keywords: apparent death, seemingly dead, legend, rumour, Lazarus syndrome, funeral, Enlightenment, $19^{\text {th }}$-century Estonian journalism, premature burial

Storylines associated with apparent death are known all over the world. Hardly any other subject or motif of folklore can offer a more coloured bouquet in genre than apparent death, ranging from fairy tales and romantic legends and narratives to rumours, ballads, and jokes. The earlier texts of our folklore archives date back to the late 1880s, but the vast majority of Estonian apparent death stories were collected in the second half of the $20^{\text {th }}$ century. The historical origin of the stories of apparent death reaches to antiquity and probably also relies on some truthful occasions, but the formation and spread of folk tales on this subject fall into the Enlightenment period in Europe. The article focuses on the context of apparent death stories in $18^{\text {th }}-19^{\text {th }}$ century Europe, including Estonia. The emergence and developments of this topic relate to medical and religious practices, journalism and literature.

Eda Kalmre (b. 1958) PhD, Estonian Literary Museum, Department of Folklore, Senior Researcher (Vanemuise 42, 51003 Tartu), eda@folklore.ee 